\title{
Perancangan Aplikasi Informasi Data Pensiun dan Kenaikan Jabatan Pada Kantor DPRD Kabupaten Labuhanbatu Menggunakan Web
}

\author{
Sartika Dwi', M. Bobbi Kurniawan Nasution²
}

${ }^{1}$ Univesitas Al Washliyah Labuhanbatu, Rantauprapat, Indonesia

Info Artikel
Article history:
Received: 21122018
Revised: 13012019
Accepted: 28012019
Kata Kunci:
Kantor DPRD Labuhanbatu
Data Pensiun dan Kenaikan
Jabatan

Penulis Korespondensi: dwisartika90@gmail.com bobbiqu@gmail.com

\begin{abstract}
Personnel information system is a system that aims to manage personnel data, the need for information is currently increasing, this requires the performance of information to be fast and reliable in managing information. However, in this case, the implementation of the personnel information system at the Labuhanbatu DPRD office still faces several obstacles, such as in terms of processing data on pensions and promotion of positions. Therefore, the employment information system was developed with the aim of assisting the process of submitting retirement, promotion, so as to speed up work. The result of this research is a system that can assist employees in preparing the requirements for promotion of employee retirement with an integrated database..
\end{abstract}

\begin{abstract}
Abstrak
Sistem informasi kepegawaian merupakan sebuah sistem yang bertujuan untuk mengelola data kepegawaian sebuah, kebutuhan akan informasi pada saat ini semakin meningkat hal ini memnuntut kinerja sebuah informasi untuk cepat dan dapat di dapat di percaya dalam mengelola informasi. Namun dalam hal ini pelaksanaan Sistem informasi kepegawaian di Kantor DPRD Labuhanbatu masih mengalami beberapa kendala, seperti dalam hal pengolahan data Pensiun dan Kenaikan Jabat. Oleh sebab itu, maka dikembangkanlah sistem informasi kepegawaian tersebut dengan tujuan untuk membantu proses pengajuan pension,kenaikan jabatan, sehingga dapat mempercepat pekerjaan. Hasil dari penelitian ini adalah sebuah sistem yang dapat membantu pegawai dalam menyiapkan persyaratan kenaikan jabatan kepensiunan pegawai dengan adanya sebuah database yang terintegrasi.
\end{abstract}

\section{PENDAHULUAN}

Pada saat ini pengolahan informasi mengenai staff dan pegawaian pada DPRD Kabupaten Labuhanbatu sudah dilakukan dengan terkomputerisasi, artinya data-data yang mengenai kepegawaian sudah berada di dalam suatu komputer dalam program Microsoft Office Access Database pada bagian staff dan kepegawaian. Namun aplikasi tersebut masih kurang optimal yaitu aplikasi tersebut hanya sebagai tempat penyimpanan data pegawai yang bekerja di kantor DPRD Labuhanbatu, sedangkan untuk kegiatan-kegiatan administrasi kepegawaian lainnya seperti pengolahan data pensiun, data kenaikkan pangkat, data pelatihan, data pribadi pegawai, perhitungan jam kerja efektif pegawai semua proses kegiatan masih dilakukan secara manual dan pegawai tidak dapat melihat laporan absensi nya dan yakni admin atau Sub Bagian Kepegawaian.

Data staff dan pegawai yang sudah memasuki umur pensiun sedangkan untuk kenaikkan pangkat admin melihat data pegawai berdasarkan pangkat pegawai tersebut. Apabila Pangkat tersebut sudah memasuki tahun keempat maka pegawai tersebut harus dinaikkan pangkatnya dengan mengajukan surat permohonan kenaikan pangkat yang dibuat oleh Subag. Peg. TU dan SDM untuk diajukan ke Ka.Biro SDM. Selain itu buku harus diperbaharui setiap ada pegawai yang naik pangkat, pensiun, serta data-data kepegawaian lainnya seperti data pelatihan, data pendidikan, serta data pribadi pegawai. Untuk absensi menggunakan mesin fingerprint kemudian data absensi pegawai di olah ke dalam bentuk Microsoft Excel sebagai hasil laporan absensi pegawai dan di hitung secara manual jam kerja efektif nya.

Oleh karena itu dibutuhkan suatu konsep pengolahan data staff dan pegawai lengkap dengan fitur pengolahan data pensiun pegawai, pengolahan data kenaikkan pangkat, pengolahan data cuti pegawai, usulan pelatihan pegawai, pengolahan data absensi, dan laporan yang disediakan sesuai dengan kebutuhan Balai 
Besar Teknologi Energi dalam bentuk website untuk mencakup seluruh kegiatan pegawai dan memudahkan para pegawai dalam berbagai hal serta keperluan untuk menunjang kinerja para pegawai.

\section{LANDASAN TEORI}

\subsection{Sistem}

Ada dua kelompok pendekatan dalam mendefinisikan sistem. Ada yang menekankan pada prosedurnya dan ada yang menekankan pada komponen atau elemennya, diantaranya :

Pendapat pertama menekankan sistem pada komponennya. "Sistem adalah kumpulan dari elemen-elemen yang berinteraksi untuk mencapai suatu tujuan tertentu".

Pendapat kedua menekankan sistem pada prosedurnya."Sistem adalah suatu jaringan kerja dari prosedur-prosedur yang saling berhubungan, berkumpul bersama-sama untuk melakukan suatu kegiatan atau untuk menyelesaikan suatu sasaran tertentu". Andalia. dkk (2015:93).

Menurut Jogiyanto Sistem dapat didefinisikan dengan pendekatan prosedur dan pendekatan komponen. Dengan pendekatan prosedur, sistem dapat didefinisikan sebagai kumpulan dari prosedurprosedur yang mempunyai tujuan tertentu. Contoh sistem yang didefinisikan dengan pendekatan prosedur ini adalah sistem akuntansi. Sistem ini didefinisikan sebagai kumpulan dari prosedur-prosedur penerimaan kas, pengeluaran kas, penjualan, pembelian dan buku besar. Sedangkan dengan pendekatan komponen, sistem dapat didefinisikan sebagai kumpulan dari komponen yang saling berhubungan satu dengan yang lainnya membentuk satu kesatuan untuk mencapai tujuan tertentu. Contoh sistem yang didefinisikan dengan pendekatan ini misalnya adalah sistem komputer yang didefinisikan sebagai kumpulan dari perangkat keras dan perangkat lunak. Yuliawan (2013:85). Sistem merupakan suatu jaringan kerja dari prosesdur-prosedur yang saling berhubungan, berkumpul dan bersama-sama untuk melakukan suatu kegiatan atau untuk menyelesaikan suatu sasaran tertentu. Sustu sistem terdiri dari sejumlah komponen yang saling berinteraksi, saling bekerja sama membentuk satu.

\subsection{Informasi}

Informasi menurut Turban et al merupakan data yang telah diorganisir sehingga memberikan arti dan nilai kepada penerimanya. Sedangkan menurut Jogiyanto, Informasi adalah data yang diolah menjadi bentuk yang lebih berguna dan lebih berarti bagi yang menerimanya. Dapat dikatakan bahwa data merupakan bahan mentah, sedangkan informasi adalah bahan jadi atau bahan yang telah siap digunakan, Jadi, sumber dari informasi adalah data. Data merupakan bentuk jamak dari bentuk tunggal datum atau data-item. Data adalah kenyataan yang menggambarkan suatu kejadian dan kesatuan nyata. Kejadian (event) adalah sesuatu yang terjadi pada saat tertentu.

\subsection{Web}

Pengertian Web atau Situs "Website atau situs dapat diartikan sebagai kumpulan halaman halaman yang digunakan untuk menampilkan informasi, teks, gambar diam atau bergerak, animasi, suara, dan atau gabungan dari semuanya itu, baik yang bersifat statis maupun dinamis yang membentuk satu rangkaian bangunan yang saling berkait dimana masing masing dihubungkan dengan jaringan jaringan halaman (hyperlink). Menurut Muhammad Tohirudin WWW (World Wide Web) adalah kumpulan web server (penyedia web) dari seluruh dunia yang berfungsi menyediakan data dan informasi. Melalui WWW atau bisa disebut web kita dapat mengakses informasi berupa teks, gambar, suara, video, dan animasi. Yusmiarti (2016:3).

\section{ANALISA DAN PERANCANGAN}

Context diagram adalah gambaran tentang suatu sistem yang terdapat dalam suatu organisasi yang memperlihatkan batasan sistem. Adanya interaksi antara external entity dan sistem informasi utama mengalir diantara entity-entity dan sistem. Context diagram ini merupakan alat bantu yang digunakan dalam perancangan sistem yang akan dikembangkan dan menggambarkan hubungan antara elemen yang membentuk suatu kesatuan. 


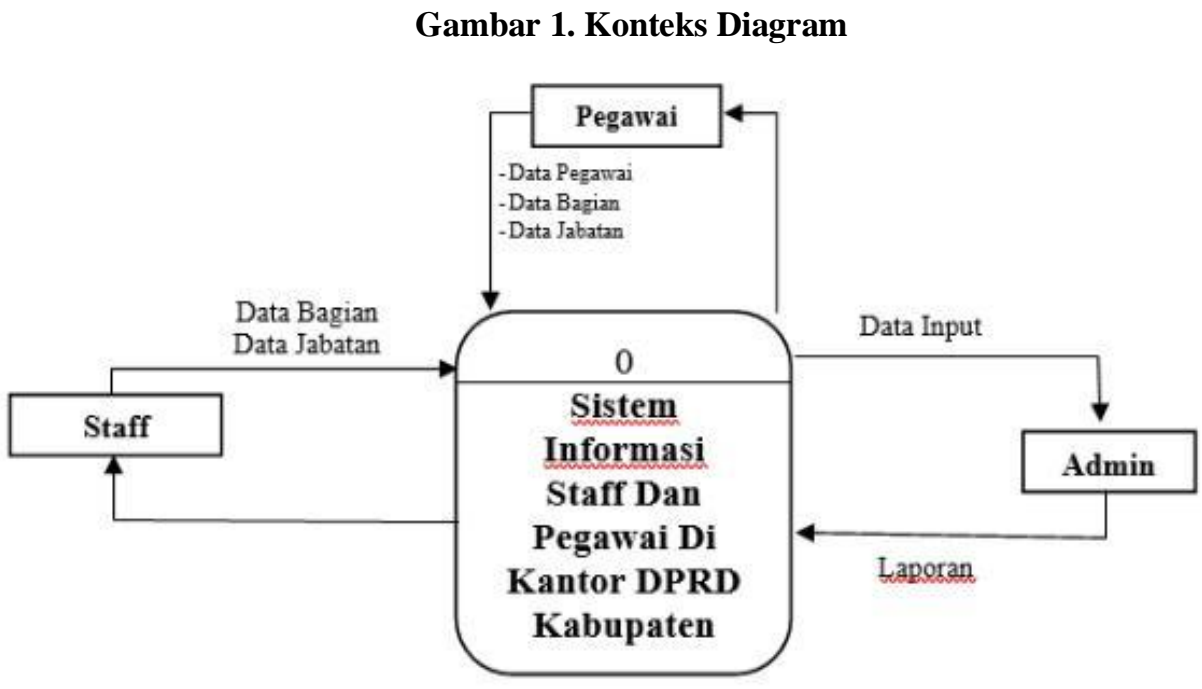

\section{IMPLEMENTASI}

\subsection{Halaman Login}

Halaman login ini sebagai tampilan yang wajib untuk memasukkan username dan password, jika username dan password dimasukkan, maka pengguna dapat masuk atau mengakses ketahap menu utama, berikut ini tampilan halaman login :

Gambar 2. Halaman Login

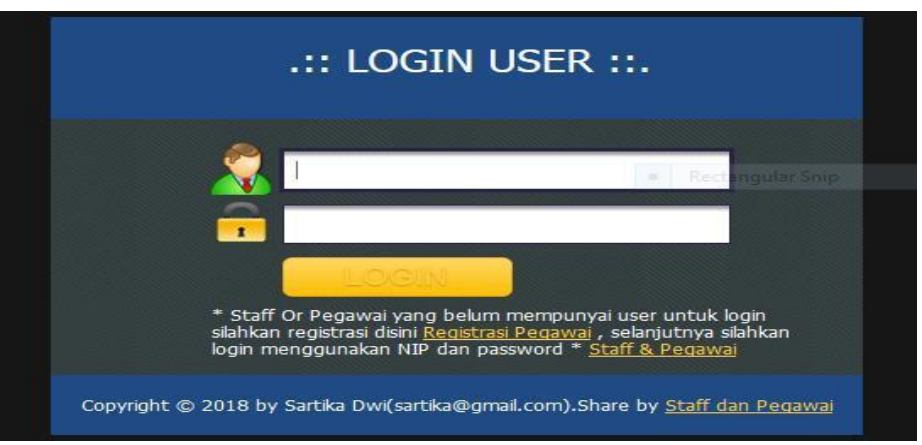

\subsection{Halaman Utama}

Setelah menu login diisi akan tampillah menu utama yang berisi seluruh tabel diatas, seperti gambar dibawah ini :

\section{Gambar 3. Halaman Utama}

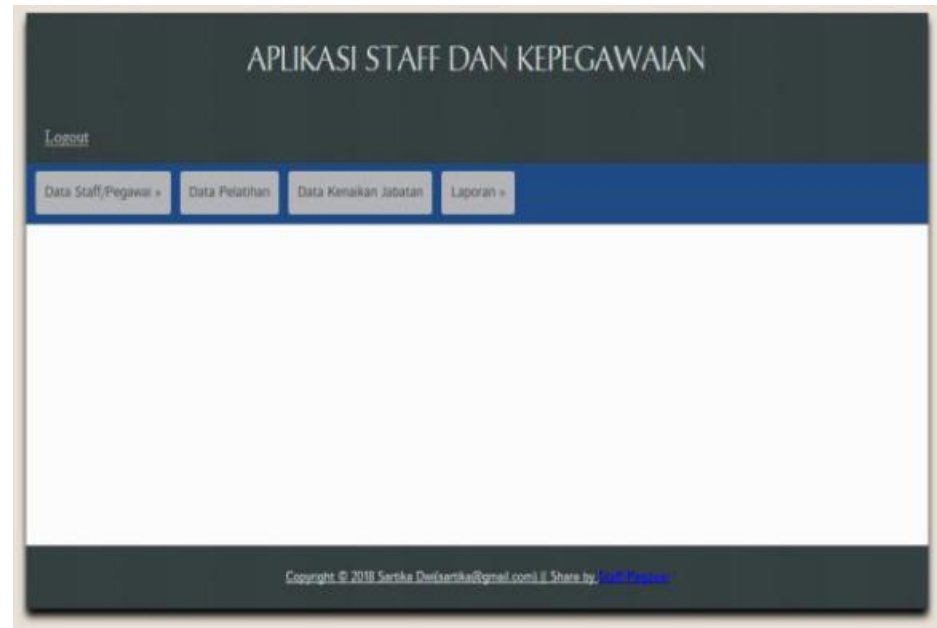




\subsection{Halaman Data Staff/Pegawai}

Dihalaman ini ada terdapat 2 halaman yaitu :

Halaman Data Bagian, halaman ini akan menjelaskan tentang id bagian, dan nama bagian, seperti gambar dibawah ini :

\section{Gambar 4. Data Pegawai}

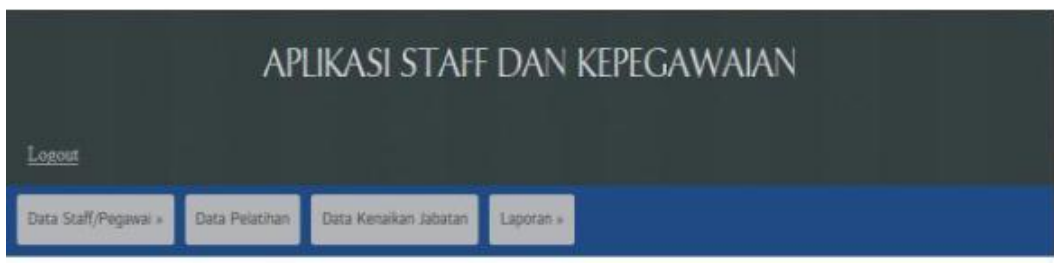

\begin{tabular}{|c|c|c|c|}
\hline \multicolumn{4}{|c|}{ Tamben Dots } \\
\hline No & Io Bagan & Nama Baglen & conedol \\
\hline 1 & Bopt & Marketing & Edr Hapov \\
\hline
\end{tabular}

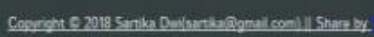

Halaman Data Jabatan, halaman ini akan menampilkan tentang id jabatan dan nama jabatan, seperti gambar di bawah ini :

\section{Gambar 5. Data Jabatan}
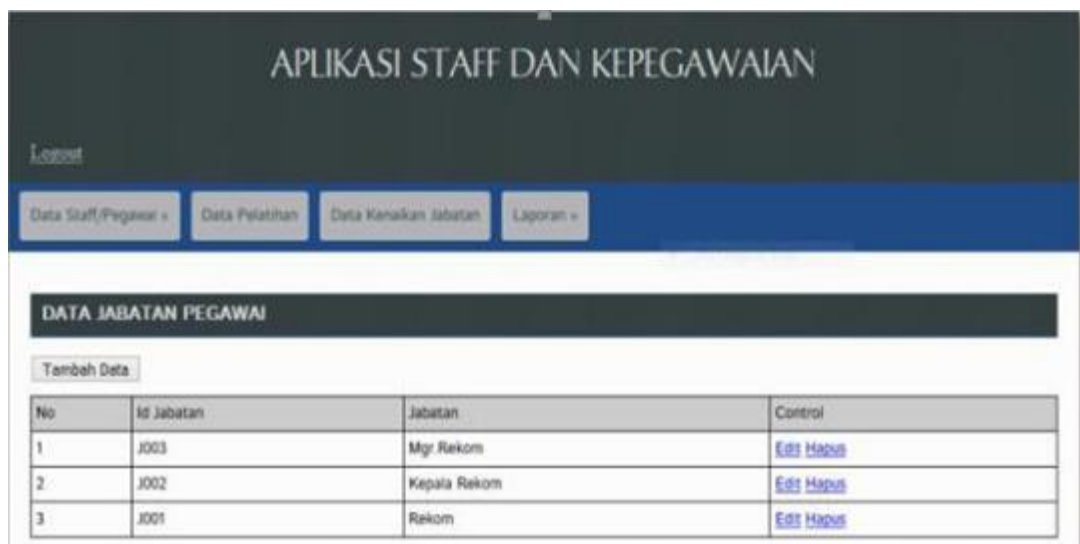

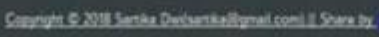

\subsection{Halaman Pelatihan}

Halaman ini akan menampilkan data pelatihan pegawai, seperti nama pelatihan, tanggal pelatihan ,dan hasil pelatihan yang akan dilalui, berikut gambar dibawah ini :

Gambar 6. Data Pelatihan

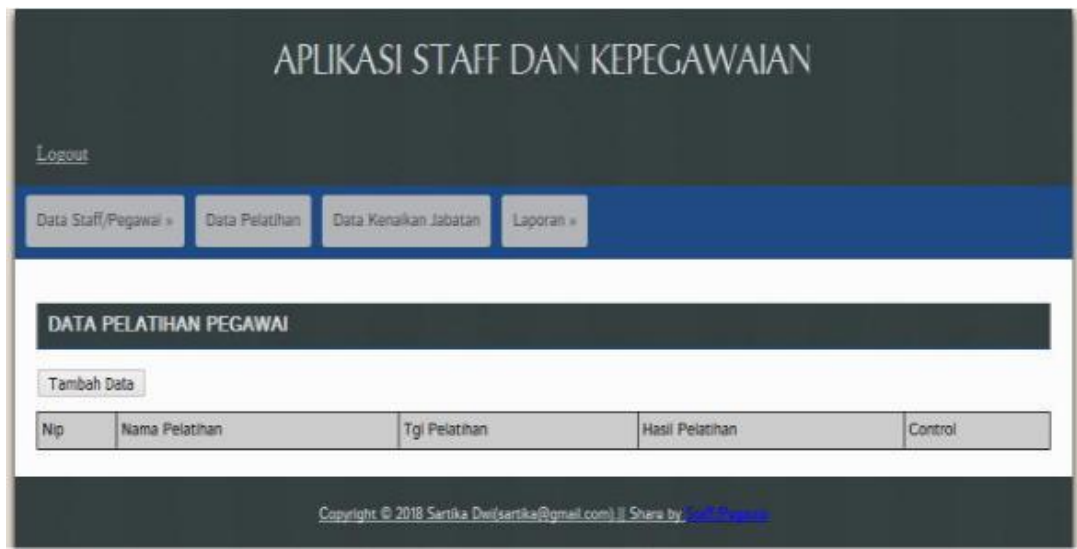

U-NET Jurnal Teknik Informatika, Vol. 03, No. 01, Februari 2019: 43-48 


\subsection{Halaman Kenaikan Jabatan}

Dihalaman ini akan ditampilkan struktur kenaikan jabatan pegawai mulai dari nama pegawai, tanggal masuk, bagian, jabatan sekarang, dan masa kerja pegawai, seperti gambar dibawah ini :

\section{Gambar 7. Data Kenaikan Jabatan}

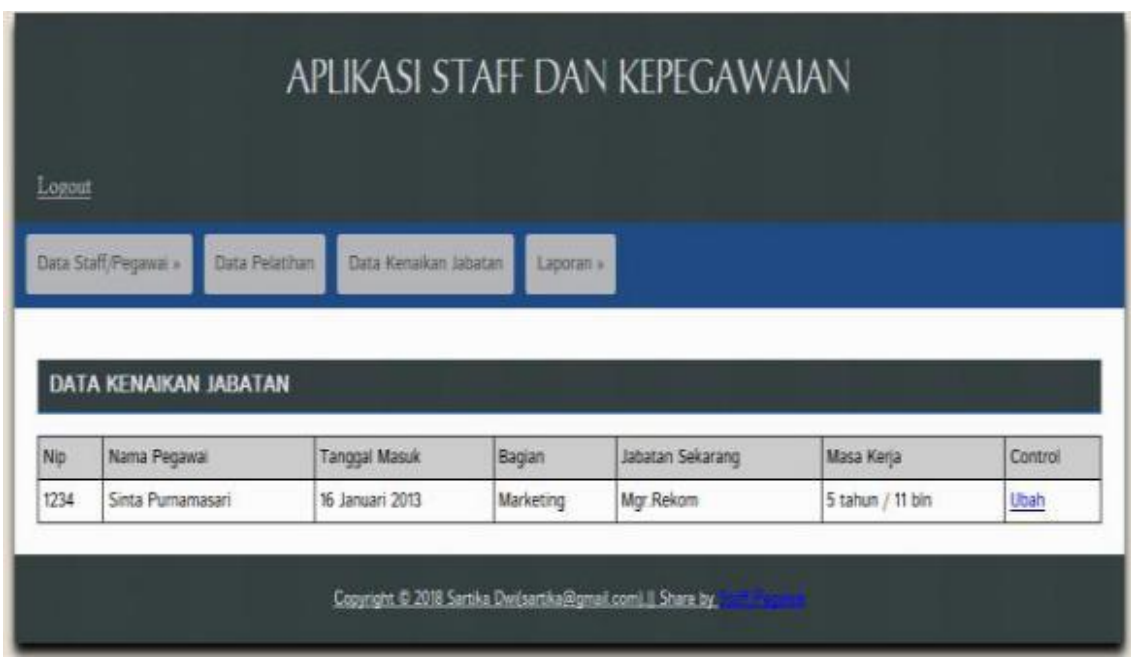

\subsection{Halaman Output}

Pada pembahasan tampilan output ini, penulis akan menampilkan tampilan output berupa laporan hasil dari input data yang, seperti gambar dibawah ini :

Gambar 8. Tampilan Output Laporan Absensi Per-Periode

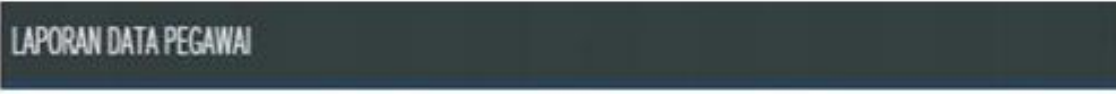

\begin{tabular}{|c|c|c|c|c|c|c|}
\hline N & $\mathrm{Np}$ & lema Pegara & Tregga Uessk & keis Kearin & latan & ketion \\
\hline 1 & W34 & 5 fra Puranasai & 6 lanus 2009 & Peremouan & Uyg Reicn & Detal Pevara \\
\hline
\end{tabular}

Cetak Halanda

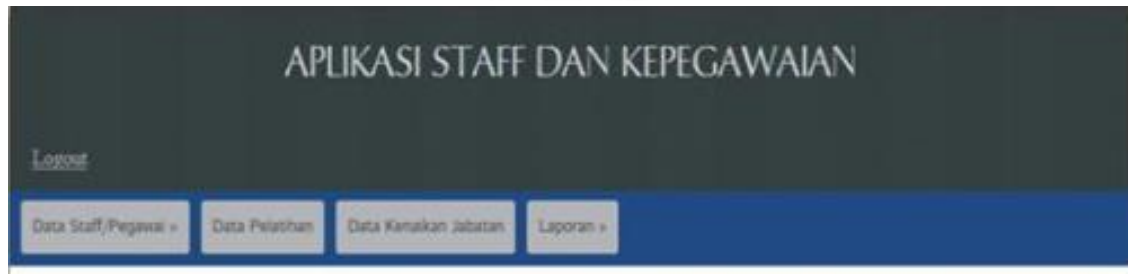

\section{LPORUN ABSENSI PER PERAOOE}

Doven $\sim 2000 \times$ Tompliso 


\section{KESIMPULAN DAN SARAN}

Adapun kesimpulan dari penelitian ini bahwa Aplikasi informasi staff dan pegawai dapat menampilkan rekap secara keseluruhan. Aplikasi informasi staff dan pegawai dapat membantu pembuatan data staff dan pegawai.

\section{REFERENSI}

[1] F. Edi, P. T. Informatika, and F. U. A. Labuhanbatu, "UNET | Jurnal Ilmiah Teknik Informatika LPPM Universitas Al Washliyah Labuhanbatu UNET | Jurnal Ilmiah Teknik Informatika ISSN . 2460-3694, Vol . 2 No . 1 Februari 2018,” vol. 2, no. 1, pp. 2-5, 2018.

[2] D. I. G. H. Wirhan Fahrozi, Samsir, "Penerapan E-Commerce Pada Toko Bunga Underwear," J. Tek. Inform., vol. 04, no. 01, pp. 1-6, 2020.

[3] P. T. Informatika and F. U. A. Labuhanbatu, "U-NET : Jurnal Teknik Informatika LPPM Universitas Al Washliyah Labuhanbatu 18 | P a g e U-NET : Jurnal Teknik Informatika Sebagai langkah awal yang dilakukan supaya dapat mengetahui gambaran permasalahan yang dihadapi oleh bagian kesiswaan adalah denga," vol. 3, no. 4, pp. 18-22, 2019.

[4] W. Fahrozi, P. T. Informatika, T. Informatika, F. U. A. Labuhanbatu, T. Mulia, and K. Medan, "UNET : Jurnal Teknik Informatika LPPM - Universitas Al Washliyah Labuhanbatu 23 |P a g e UNET : Jurnal Teknik Informatika Sebagai langkah awal yang dilakukan supaya dapat mengetahui gambaran permasalahan yang dihadapi dalam menentukan rasa yam serama a," vol. 3, no. 5, pp. 2327, 2019.

[5] Samsir, "Klasifikasi Penyakit Tenggorokan Hidung Telinga ( THT ) Menggunakan Jaringan Syaraf Tiruan Dengan Metode Learning Vektor Quantization ( THT ) Di RSUD Rantauprapat Labuhanbatu Klasifikasi penyakit Tenggorokan Hidung Telinga ( THT ) Menggunakan,” vol. 05, no. 01, pp. 3847, 2019.

[6] D. Indra et al., "SPK Untuk Pemilihan Kepala Sekolah Menggunakan Metode Saw dan Profile Matching," vol. 4, no. 1, pp. 7-12, 2020.

[7] M. Siddik and S. Samsir, "Rancang Bangun Sistem Informasi Pos (Point of Sale) Untuk Kasir Menggunakan Konsep Bahasa Pemrograman Orientasi Objek," JOISIE (Journal Inf. Syst.

Informatics Eng., vol. 4, no. 1, p. 43, 2020, doi: 10.35145/joisie.v4i1.607.

[8] Samsir and Syaiful Zuhri Harahap, "Application Design Resume Medical By Using Microsoft Visual Basic. Net 2010 At the Health Center Appointments,” Int. J. Sci. Technol. Manag., vol. 1, no. 1, pp. 14-20, 2020, doi: 10.46729/ijstm.v1i1.5.

[9] M. V. B. Net, "PADA TOKO URIP MOTOR,” no. September, pp. 1-6, 2020.

[10] J. H. P. Sitorus et al., "Perancangan pengontrol lampu rumah miniatur dengan menggunakan micro controler arduino berbasis android 1," vol. 4, no. 1, pp. 1-11, 2020.

[11] U. Verawardina, F. Edi, and R. Watrianthos, "Analisis Sentimen Pembelajaran Daring Pada Twitter di Masa Pandemi COVID-19 Menggunakan Metode Naïve Bayes,” vol. 5, pp. 157-163, 2021, doi: 10.30865/mib.v5i1.2604.

[12] S. Zulkifli, "Implementasi Sistem Keamanan SQL Injection Dalam berbasis web," Ejurnal.Univalabuhanbatu.Ac.Id, vol. 04, no. 01, pp. 13-17, 2020, [Online]. Available: https://ejurnal.univalabuhanbatu.ac.id/index.php/u-net/article/download/164/130. 